\title{
Hrvatski znanstvenici u razvoju tehničke mehanike XX. stoljeća
}

\author{
Ivo Alf irević \\ Fakultet strojarstva i brodogradnje Sveučilišta u Zagrebu \\ ivo.alfirevic@fsb.hr
}

SAŽETAK: Tehnička mehanika počela se izdvajati iz klasične mehanike na prijelazu iz XVIII. u XIX. stoljeće, tj. početkom industrijske revolucije, čemu je pridonijelo osnivanje visokih tehničkih škola u Europi. U Hrvatskoj se tehnička mehanika počela razvijati u drugoj polovici XIX. stoljeća, a naročito nakon osnivanja Visoke kraljevske tehničke škole 1919. u Zagrebu. Rad donosi biografije uglednih hrvatskih, ali i stranih znanstvenika, koji su pridonijeli razvoju tehničke mehanike u Hrvatskoj u XX. stoljeću.

Ključne riječi: tehnička mehanika; XX. stoljeće; Peter Salcher; Ivan Blaž Lupis; Sándor Alexander Riegler; Vinko Dvořák; Vinko Hlavinka; Stjepan Prokofjevič Timošenko; Konstantin Čališev

\section{Uvod}

Tehnička mehanika počela se izdvajati iz klasične mehanike na prijelazu iz XVIII. u XIX. stoljeće, tj. početkom industrijske revolucije, čemu je pridonijelo osnivanje visokih tehničkih škola, ponajprije École polytechnique u Parizu, ETH (Eidgenössische Technische Hochschule) u Zürichu i Technische Hochschule u Charlottenburgu kraj Berlina. Tehnička je mehanika pretežno deduktivna znanost koja se temelji na osnovnim zakonima klasične mehanike: Newtonovim zakonima, zakonu gravitacije i paralelogramu sila i pomaka. Svrha joj je razviti što jednostavnije postupke mehaničke analize konstrukcija, strojeva i vozila.

U Hrvatskoj se tehnička mehanika počela razvijati u drugoj polovici XIX. stoljeća, a naročito nakon osnivanja Visoke kraljevske tehničke škole 1919. u Zagrebu. Važnu ulogu u razvoju hrvatske tehničke mehanike imao je premještaj glavne austrougarske ratne luke u Pulu i vezano s tim premještaj stručne tehničke biblioteke iz Venecije i Trsta u Pulu kao i osnivanje Mornaričke akademije (k.k. Marine Cadettenschule, Cesarea regia scuola dei cadetti di marina) 1848. u Rijeci, osnivanje modernoga Sveučilišta u Zagrebu 1874. te osnivanje Družtva inžinira i arhitekta 1878. u Zagrebu. 


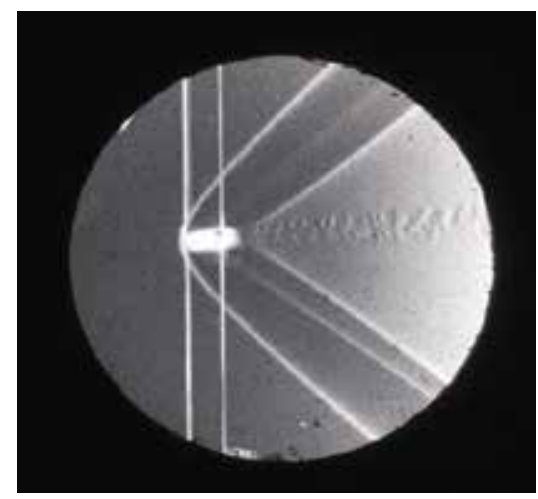

Pojave koje prate let puščanoga zrna. Snimio Peter Salcher

\section{Tehnička mehanika do kraja Prvoga svjetskoga rata}

Razvoj tehničke mehanike bit će prikazan opisom života i rada uglednih hrvatskih znanstvenika koji su djelovali u Hrvatskoj i inozemstvu, kao i stranih znanstvenika koji su djelovali u Hrvatskoj i bili prihvaćeni u novoj sredini. Među najistaknutije spadaju Peter Salcher (1848-1928), profesor fizike i mehanike na Mornaričkoj akademiji u Rijeci, suradnik Ernsta Macha za kojega je u tvornici torpeda snimio fotografiju puščanoga zrna u letu, Ivan Blaž Lupis (1813-1875), izumitelj torpeda, i Sándor Alexander Riegler, profesor i ravnatelj Mađarske gimnazije u Rijeci. Na Sveučilištu u Zagrebu djelovali su Vinko Dvořák i Vinko Hlavinka.

Vinko (Vincenc, Čeněk) Dvořák, hrvatski fizičar češkoga podrijetla (Dušejov, Češka, 1848 - Zagreb, 1922). Na Karlovu sveučilištu u Pragu diplomirao je matematiku i fiziku 1871. i doktorirao 1873. te potom postao asistent Ernsta Macha. Nakon dvije godine preselio u Zagreb, gdje je postao prvi profesor fizike na obnovljenom sveučilištu, na kojemu je radio sve do umirovljenja 1911., osnovavši 1875. Fizikalni kabinet. U dva je mandata bio dekan Mudroslovnoga fakulteta i rektor Sveučilišta u Zagrebu 1893/94. Predavao je teorijsku i eksperimentalnu fiziku kao i povijest fizike. Unatoč veoma skromnim materijalnim sredstvima, $\mathrm{i}$

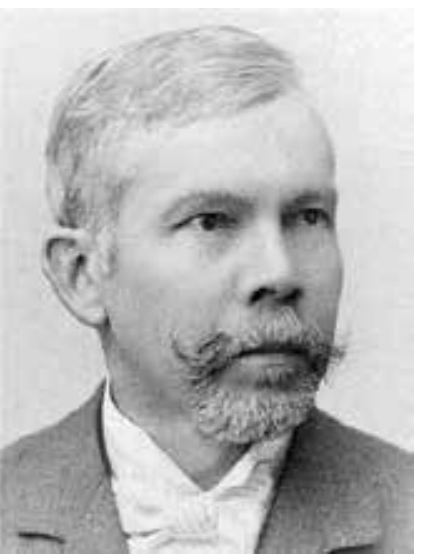

Vinko Dvořák činjenici da je bio jedini čovjek u Fizikalnom kabinetu, intenzivno se bavio i znanstvenom djelatnošću. Naročito uspješne rezultate postigao je na području akustike i mehanike (Dvořák-Rayleighova cirkulacija), mehaničkoga djelo- 
vanja zvuka na rezonatore, a zapaženi su i njegovi radovi iz povijesti fizike. Svojim istraživanjima u području akustike, optike, hidrodinamike, elektriciteta i povijesti fizike pridonio je i razvoju mehanike. $U$ akustici je istraživao titranje zraka u cijevima i otkrio tzv. stijene u trbusima titranja (1874), cirkulaciju (1875), koju je objasnio (1883) J. W. S. Rayleigh. Objasnio je pojavu akustičkoga odbijanja i privlačenja (1875.), izradio mjerač apsolutnoga intenziteta zvuka (1881), istraživao je djelovanje zvuka na rezonatore (Dvorákovo kolo, Dvoŕákove rotacijske sprave) te izradio je uređaj za mjerenje jakosti tona određene visine (Dvořákov zvukomjer). Bio je član Jugoslavenske akademije znanosti i umjetnosti (JAZU), Češke akademije, Kraljevskoga češkoga društva znanosti, Francuskoga fizikalnoga društva, Društva čeških matematičara i Hrvatskoga prirodoslovnoga društva.

Vinko (Vincenc) Hlavinka, češki i hrvatski građevinski inženjer (Vincencov kraj Prostějova, Češka, 1862 - Brno, Češka, 1934). Realnu gimnaziju završio je u Prostějovu, studij građevinarstva na Visokoj poljodjelskoj školi u Beču 1886. Po završetku studija kratko je radio u tehničkom uredu u Pragu. Godine 1887. odselio u Hrvatsku, zaposlivši se se pri Zemaljskoj vladi u Zagrebu. Nakon osnivanja Šumarske akademije u Zagrebu 1898. imenovan je profesorom geodezije, tehničke i građevne mehanike, gradnje cesta i šumskih željeznica, vodogradnje i mostogradnje. Na Šumarskoj akademiji predavao do kraja školske godine 1910/11., a zatim otišao za profesora na Visoku tehničku školu u Brnu. Bio je član Družtva inžinira i arhitekata u Hrvatskoj i Slavoniji od 1891. i 1905-10. glavni urednik glasila Viesti Hrvatskog družtva inžinira i arhitekata. Društvo mu je 1903. povjerilo izradbu prijedloga o potrebi osnivanja Visoke tehničke škole u Zagrebu.

\section{Tehnička mehanika od kraja Prvoga do kraja Drugoga svjetskoga rata}

Znatniji razvoj tehničke mehanike započeo je nakon osnivanja Visoke tehničke kraljevske škole, koja je 1926. postala Tehnički fakultet Sveučilišta u Zagrebu, čemu su uvelike pridonijeli strani profesori koji su prebjegli u Hrvatsku nakon izbijanja Oktobarske revolucije. Među njima se ističu S. P. Timošenko i K. Čališev.

Stjepan Prokofjevič Timošenko (ukr. Stepan Prokopovič Tymošenko, rus. Stepan Prokofjevič Timošenko, engl. Stephen Timoshenko), ukrajinski inženjer (Špotovka, Ukrajina, 1878 - Wuppertal, Njemačka, 1972). Gimnaziju je završio 1896. u Romni na sjeveru Ukrajine. Diplomirao je 1901. na Politehničkom prometnom institutu u Sankt Peterburgu, na kojem je ostao raditi kao asistent. Oženio se 1902. Aleksandrom Arhangelskom i s njom imao troje dje- 
ce. U laboratoriju za mehaniku Politehničkoga instituta u Sankt Peterburgu počeo raditi 1903. Nakon dvije godine prešao je na Sveučilište u Göttingenu, gdje je proveo godinu dana i surađivao sa znanstvenikom Ludwigom Prandtlom. Od 1906. do 1911. radio je na Građevinskom fakultetu Politehničkoga instituta u Kijevu, gdje je bio izabran za dekana Građevinskoga odjela, na kojemu je započeo početna istraživanja u području metode konačnih elemenata primjenom Rayleighove metode te 1911. objavio prvu verziju poznate knjige Otpornost materijala (Курс сотротивления материалов). Zbog političkih razloga otpušten je 1911. Godine

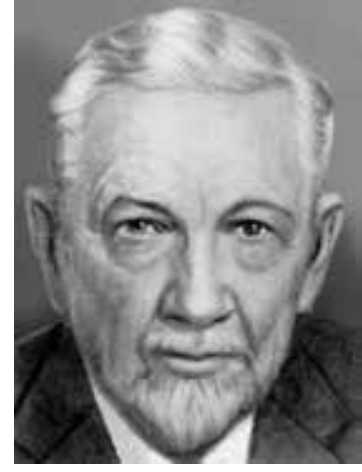

Stjepan Prokofjevič Timošenko 1913. ponovno je zaposlen na Politehničkom institutu u Sankt Peterburgu, gdje je naslijedio slavnoga profesora Alekseja Nikolajeviča Krylova.

Kad je 1917. proglašena Ukrajinska Narodna Republika vratio se u Kijev, gdje je bio jedan od osnivača i član Ukrajinske akademije znanosti. Bio je osnivač i prvi ravnatelj Instituta tehničke mehanike. Kad je armija carskoga generala 1911. zauzela Kijev, Ukrajinska akademija znanosti je zatvorena, a Timošenko je ostao bez posla. Sljedeće su godine boljševici preuzeli vlast u Kijevu, a Timošenko je s porodicom izbjegao prvo u Beograd, a zatim u Zagreb. Za redovitoga profesora Visoke tehničke škole izabran je 8. studenog 1920. Predavao je Nauku o čvrstoći, Ispitivanje gradiva, Specijalna poglavlja iz tehničke mehanike $i$ Gradevnu statiku. Sa svojom je obitelji živio u dvije prostorije Kemijskoga instituta na Marulićevu trgu 29. Neprimjerene stambene prilike i ograničene mogućnosti znanstvenoga rada potaknule su ga da nakon dvije godine napusti Zagreb i ode u SAD.

No njegov je kratkotrajan boravak u Zagrebu ostavio trajne i neizbrisive tragove: prvu je godinu posvetio utemeljenju i organizaciji Zavoda za ispitivanje gradiva te nabavci strojeva i uređenju laboratorija, dok je tijekom druge godine objavio 14 radova u britanskim, njemačkim i francuskim časopisima, tri rada u Glasniku Hrvatskoga prirodoslovnoga društva i sedam radova u Tehničkom listu. Ističu se dva rada o utjecaju smicanja na poprečne vibracije grede koja su objavljena u britanskom časopisu The London, Edinburgh, and Dublin Philosophical Magazine and Fournal of Science: prvi iz 1921., On the correction factor for shear of the differential equation for transverse vibrations of bars of uniform cross-section, na str. 744, i drugi iz 1922., On the transverse vibrations of bars of uniform cross-section, na str. 125. U tim je radovima uveden novi pojam, kasnije nazvan Timošenkova greda. 
Smatra se ocem tehničke mehanike. Objavio je, među ostalim, 18 knjiga, koje su prevedene na mnoge jezike. Bio je član devet akademija znanosti, proglašen počasnom doktorom znanosti na osam sveučilišta, među kojima i na Sveučilištu u Zagrebu 1956. Sredinom 1922. otišao je u SAD, oko godinu dana radio u Philadelphiji, potom pet godina u Westinghausu u Pittsburghu. Od 1927. bio je profesor na Sveučilištu u Michiganu, a od 1936. pa do umirovljenja 1944. profesor tehničke mehanike na Sveučilištu Stanford. Godine 1960. preselio se k svojoj kćerki u Wuppertal gdje je živio do smrti. Prije Drugoga svjetskoga rata i dva puta nakon njega posjetio je Zagreb i obišao sva mjesta gdje je nekada radio i boravio. Dopisivao se, među ostalima, is profesorom Bazjancem.

Konstantin Čališev, hrvatski inženjer građevinarstva ukrajinskoga podrijetla (Kupjansk, Ukrajina, 1888 - Zagreb, 1970). Maturirao je 1906. na realnoj gimnaziji u Izjumu, a diplomirao građevinarstvo na kijevskom Politehničkom Institutu 1911. Od 1913. držao vježbe iz nauke o čvrstoći i mehanike na Politehničkom prometnom institutu u Sankt Peterburgu. Nakon Prvoga svjetskoga rata ostao je u Kijevu kao asistent na Akademiji znanosti. Otišao je 1919. u Njemačku na službeno putovanje, s kojega se više nije vratio u Rusiju. Nakon kratka boravka u Njemačkoj, došao je u Zagreb, gdje je postao Timošenkov asistent i nakon njegova odlaska predstojnik Zavoda za ispitivanje gradiva, sve do rujna 1959. Prvi je 1922. doktorirao na Visokoj tehničkoj školi i iste godine razvio jedan od prvih relaksacijskih postupaka rješavanja jednadžbi metode pomaka. $\mathrm{U}$ radovima $\gg \mathrm{O}$ dopunitbenim naprezanjima rešetkastih nosača « (Tehnički list Udruženja jugoslavenskih inženjera i arhitekata, 1922., br. 1-2), »Izračunavanje višestruko statički neodređenih sistema pomoću postepenih aproksimacija« (Tehnički list Udruženja jugoslavenskih inženjera i arhitekata, 1923., br. 17-21), »Die Methode der sukzessiven Annaherungen bei der Berechnung von vielfach statisch unbestimmtem Systemen« (L. Karner, M. Ritter /ur./, Proceedings of the IABSE, vol. 4, Zurich 1936) uveo je relaksacijski postupak u proračun statički neodređenih konstrukcija. Nažalost, osim u bivšoj Jugoslaviji, ta je metoda ostala nezapažena jer je objavljena na slabo poznatom jeziku. Deset godina poslije Hardy Cross (1885-1959) razvio je moment distribution method, metodu vrlo sličnu Čališevoj koja je uskoro postala poznata u cijelom svijetu pod nazivom Crossova metoda. Jedan je od osnivača Jugoslavenskog društva za mehaniku (JDM) 1954. na Bledu.

Milivoj Prejac, matematičar i fizičar (Desinić, 1884 - Zagreb, 1972). Diplomirao je na Mudroslovnom fakultetu Kraljevskoga sveučilišta u Zagrebu 1906., gdje je doktorirao 1913.Nakon diplomiranja bio je profesor na gimnaziji u Bjelovaru, a od 1919. na Tehničkoj visokoj školi u Zagrebu, gdje je od 1922. bio redoviti profesor te dekan Odjela strojarstva, elektrotehnike, brodograd- 
nje i brodostrojarstva 1925-26. U nastavu je kao kolegije uveo i potom predavao teorijsku mehaniku i hidrauliku. Pripada plejadi nastavnika koji su razvili sveučilišnu nastavu tehničkih studija u Hrvatskoj i uspjeli ju zadržati u Zagrebu unatoč višestrukim nastojanjima vlade u Beogradu na smanjenju ili čak ukidanju tehničkih studija u Hrvatskoj. Objavio je nekoliko radova iz mehanike, među ostalim "Savijanje tankih ploča promjenljive deblijine« (Tehnički list, 15. V. 1922), »O vlastitim ili slobodnim titranjima štapova i ploča promjenljive debljine« (Godišnjak Sveučilišta Kraljevine fugoslavije, 1929). Objavio je i skripta iz meha-

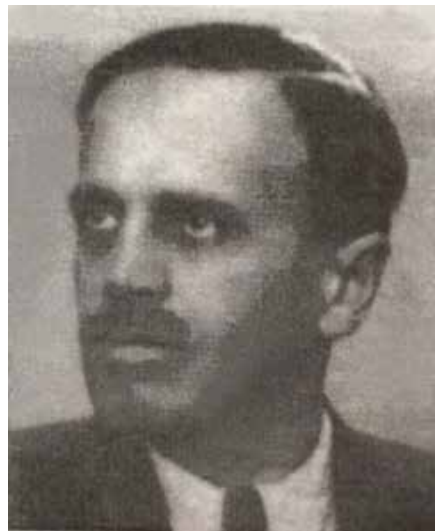

Milivoj Prejac nike prije 1940. koja su ponovno tiskana 1942. i 1943. Nakon 1945. prisilno je umirovljen u 61 . godini života.

Rajko Kušević, inženjer građevinarstva (Ilok, 1894 - Zagreb, 1966). Diplomirao je 1917. na građevinskom odjelu Tehničke visoke škole u Grazu, a doktorirao 1923. na Tehničkoj visokoj školi u Zagrebu. Tijekom 1921. boravio je u Beču na specijalizaciji iz područja čeličnih konstrukcija. Koncem 1922. počeo je raditi na Katedri za mostogradnju na Tehničkoj visokoj školi u Zagrebu, gdje je 1941. postao redoviti profesor. Predavao je građevnu mehaniku i željezne konstrukcije na Arhitektonskom odjelu Tehničkoga fakulteta, a na Građevinskom odjelu višu građevnu statiku. Objavio je više znanstvenih radova iz područja teorije konstrukcij, te knjige Statičko proračunavanje okvirnih nosača I i II (1933). Bio je glavni urednik časopisa Tehnički list (1923-39). Izabran je za dopisnoga člana JAZU (1949). Jedan je od osnivača JDM-a 1954. na Bledu.

Otto Werner, inženjer građevinarstva (Ruma, Srijem, 1908 - Zagreb, 1981). Diplomirao je 1931., a doktorirao 1941. na Tehničkom fakultetu u Zagrebu, na Građevinskom odjelu kojega je radio kao asistent 1933-36. Nakon toga radio u tvornici cementa u Podsusedu do 1946., a zatim u Arhitektonskom projektnom zavodu Plan. Od 1954. ponovno se zaposlio na Građevinskom odjelu Tehničkoga fakulteta, gdje je 1959. izabran za redovitoga profesora. Kao projektant-konstruktor tijekom radnoga je vijeka najviše radio na industrijskim građevinama, posebice tvornicama cementa u Podsusedu, Beočinu, Splitu, Brazilu, Mauricijusu, Keniji, Nigeriji, Venezueli, na Réunionu i drugim. Njegova konstrukcija, poznata kao Wernerova ljuska, izvedena je na mnogim objektima u zemlji i svijetu. Objavio je više znanstvenih radova. Dobitnik je Nagrade za životno djelo 1977. 


\section{Tehnička mehanika nakon Drugoga svjetskoga rata}

Davorin Bazjanac, inženjer strojarstva (Beravci kraj Slavonskog Broda, 1902 - Zagreb, 1988). Koncem 1918. godine polazio kadetsku školu u Karlovcu pa prešao na Višu vojnu realku u Mariboru, a zatim na Vojnu akademiju u Beogradu, gdje je 1923. dobio čin artiljerijskoga potporučnika.

Nakon dvije godine studija na Mašinskom odsjeku Tehničkoga fakulteta u Beogradu, otišao dvije godine na l'École d'application d'artillerie de Fontainebleau u Francusku gdje je proučavao balistiku, mehaniku topova i metalurgiju. Vratio se 1927. i zaposlio u Vojno-tehničkom zavodu u Kragujevcu, gdje je nadzirao podizanje nove tvornice pje-

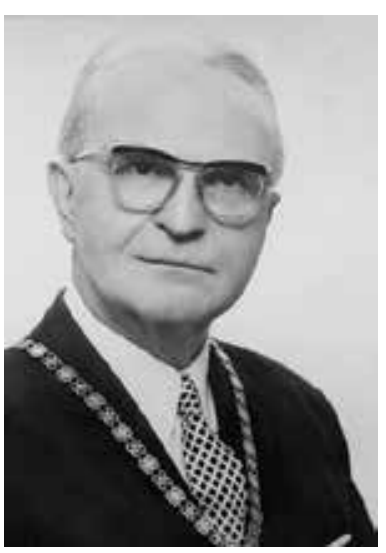

Davorin Bazjanac šačkoga streljiva. Rukovodio je izradom alata i balističkim ispitivanjem municije, zbog čega je često boravio u tvornicama u tadašnjoj Čehoslovačkoj. Od 1932. do 1935. studira strojarstvo na ETH-u u Zürichu. Ispit za majora položio je 1937., nakon čega je postao upravitelj 4. odjeljenja Vojno-tehničkog zavoda u Kragujevcu. Nakon kapitulacije Jugoslavije preselio se u Zagreb. Doktorsku disertaciju Untersuchungen mit Hilfe der elektrischen Analogie über den Einfluss der Luftstrahlbegrenzung in Windkanälen auf Tragflügelmessungen obranio je 1943. na ETH-u u Zürichu.

Od jeseni 1945. kratko je radio u Srednjoj tehničkoj školi u Zagrebu, a zatim prešao na Tehnički fakultet u Zagrebu, na kojem je 1954. izabran za redovitoga

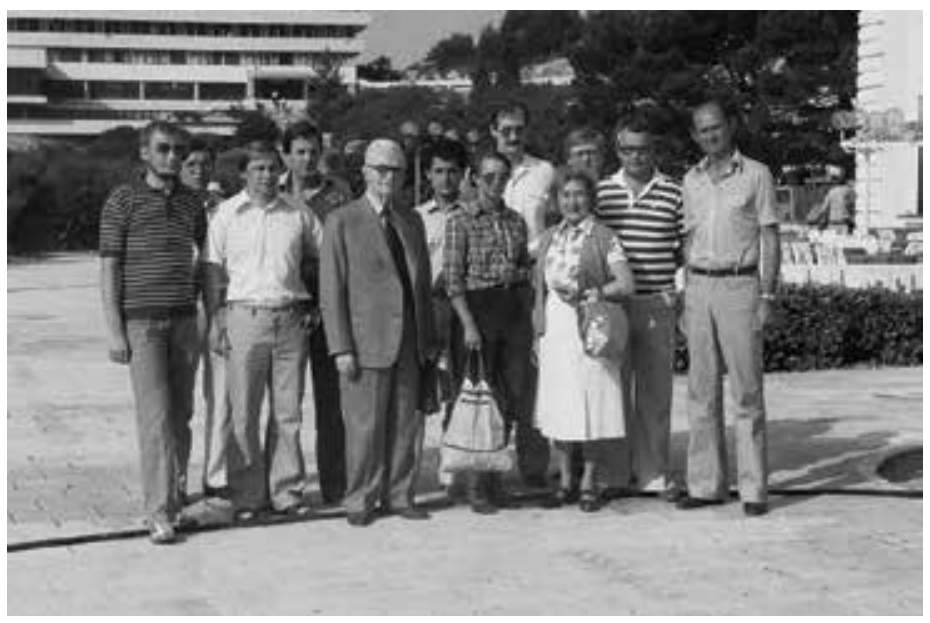

Profesor Bazjanac okružen suradnicima, Kupari 1981. 
profesora. Uveo je u nastavu vektorski pristup tehničkoj mehanici, istražujući u području eksperimentalne mehanike.

Objavio je više od 50 znanstvenih i stručnih radova, pet sveučilišnih udžbenika, 15 skripata i zbirki zadataka. Obnašao je dužnost dekana i prodekana na Strojarsko-brodograđevnom fakultetu (SBF). Bio je osnivač (1969) i prvi predsjednik Hrvatskoga društva za mehaniku (HDM), jedan od osnivača JDM-a 1954. na Bledu i njegov predsjednik dva mandata, počasni član JDM-a i HDM-a, predsjednik Jugoslavenskoga nacionalnoga komiteta Međunarodne federacije za teoriju mašina i mehanizama (IFToMM) i jedan od pokretača osnivanja Centra za mehaničke znanosti u Udinama (CISM). Bio je višegodišnji suradnik JAZU. Od 1960. do 1970. sudjelovao je u osnivanju tehničkih fakulteta u Rijeci, Splitu, Osijeku i Slavonskom Brodu. Početkom 1960-ih komentirao je i prikazivao svemirske letove SAD-a i SSSR-a. Po njemu su nazvane dvije ulice, u Zagrebu i Slavonskom Brodu, te nagrada Fakulteta strojarstva i brodogradnje (FSB) koja se dodjeljuje studentima prvih triju godina preddiplomskih studija za izvrsnost u studiranju.

Vasilij Andrejev, hrvatski inženjer geodezije i građevinarstva ruskoga podrijetla (Nižne-Čirsk, 1904 - Zagreb, 1988). U Jugoslaviju je došao 1920. u petom razredu srednje škole, koju je završio 1924. u Bileći. Diplomirao je geodeziju 1929., a građevinarstvo 1934. na Tehničkom fakultetu u Zagrebu, gdje je i doktorirao 1952. Nakon diplomiranja radio je u privredi. Zaposlio se na Tehničkom fakultetu 1946. kao honorarni nastavnik. Nastavu tehničke mehanike preuzeo je od profesora Milivoja Prejca. Osim na Građevinskom fakultetu, predavao je mehaniku i teoriju elastičnosti i na drugim fakultetima u Sarajevu, Banjoj Luci i Splitu. Umirovljen je 1974. Radove je objavljivao u Šumarskom listu, Tehničkom listu, Inženjeru i drugi domaćim časopisima. Napisao je tri sveučilišna udžbenika. Uložio je velik trud u odgoj mladih znanstvenika i nastavnika. Pod njegovim mentorstvom osposobljeni su mnogi nastavnici mehanike na Građevinskom, Arhitektonskom i Geodetskom fakultetu u Zagrebu te na Mašinskom fakultetu u Sarajevu. Jedan je od osnivača JDM-a 1954. na Bledu.

Eugen Erlih, inženjer građevinarstva (Zagreb, 1913 - Zagreb, 2003). U Zagrebu je završio realnu gimnaziju 1931. i diplomirao 1937. na Građevinskom odsjeku Tehničkoga fakulteta, na kojem je ostao raditi kao asistent. Redoviti profesor mehanike, armirano-betonskih konstrukcija i konstruktivnih sistema postao je 1971. na Arhitektonskom fakultetu u Zagrebu. Objavio je 1966. skripta Osnovi statike krutih tijela.

Zlatko Kostrenčić, inženjer građevinarstva (Zagreb, 1915 - Zagreb, 1991). Na Građevinskom odjelu Tehničkoga fakulteta u Zagrebu diplomirao je 1939., 
postao asistent 1945. i doktorirao 1953. Na istom fakultetu postao je redoviti profesor 1970. te bio dekan od 1969. do 1973. Predavao je na Sveučilištu u Khartumu u Sudanu 1957-59. Bavio se područjima otpornosti materijala, ispitivanja konstrukcija, teorije elastičnosti, teorije plastičnosti i dr. Bio je jedan od pionira eksperimentalne mehanike u Hrvatskoj i proveo je prva mjerenja konstrukcija elektrootporničkim tenzometrima (1949). Objavio je mnogobrojne znanstvene i stručne radove te udžbenik Svojstva lakih betona i Teorija elastičnosti. Dobitnik je Nagrade za životno djelo 1986. Bio je jedan od osnivača JDM-a 1954. na Bledu i HDM-a u Zagrebu 1969.

Zlatko Modor, inženjer građevinarstva (1916-1966). Na Građevinskom odsjeku Tehničkoga fakulteta u Zagrebu diplomirao i doktorirao, te od 1947. bio asistent na katedri Otpornost materijala, koju je preuzeo 1964. Unatoč preranoj smrti, ostao je zapamćen kao vrstan pedagog, ali i kao znanstvenik i stručnjak. Bio je jedan od osnivača JDM-a 1954. na Bledu. O njemu Krešimir Herman piše:

Predavanja iz Otpornosti materijala preuzima 1964. godine doc. dr. Zlatko Modor, no nažalost, ovaj bez dvojbe izvanredno talentirani znanstvenik i nastavnik umro je mlad nakon što je izveo dvije generacije studenata. Dolazi u Zavod 1947. godine kao asistent, te ubrzo stječe glas nenadmašnog pedagoga kojeg $i$ dandanas spominju generacije ondašnjih studenata. Strog $i$ pravedan na ispitima, s beskrajnom je strpljivošću studentima u svakoj prilici tumačio misterij naprezanja $i$ deformacije. Pamti se i kao izvrstan stručnjak za numeričke metode proračuna, te je $i$ doktorirao iz tog područja. Stoga je uvijek poklanjao veliku pozornost edukaciji studenata numeričkim metodama izračuna. Kao doktor tehničkih znanosti bio je više od sedam godina asistent jer mu je kao časniku hrvatske vojske bilo zapriječeno napredovanje. Iako je radio u teškim uvjetima, svojim je djelovanjem, a posebice svojom visokom razinom predavanja i vježbi, dao značajan doprinos razvoju zagrebačke škole otpornosti materijala.

Zorislav Sapunar, inženjer strojarstva (Ložišće na Braču, 1920 - Rijeka, 1988). Diplomirao je 1949. na Mašinskom fakultetu u Beogradu, a doktorirao 1965. na Strojarsko-brodograđevnom fakultetu u Zagrebu s tezom iz teorije mehanizama. Nakon diplomiranja zaposlio se u Upravi za koordinaciju rada znanstvenih instituta u Beogradu. Godine 1951. postao je znanstveni suradnik u Konstrukcijskom birou Odjela za aerodinamiku Generalne direkcije vazduhoplovne industrije. Od 1952. do 1960. godine radio je na Srednjoj tehničkoj školi, a zatim i na Višoj stručnoj pedagoškoj školi u Rijeci. Odmah po osnivanju Strojarskoga fakulteta u Rijeci 1960. izabran je u zvanje predavača. Istodobno je postao prodekan i tu dužnost obavljao do 1964. Voditelj je Kate- 
dre tehničke mehanike, a zatim i predstojnik Zavoda za tehničku mehaniku. Dužnost dekana Strojarsko-brodograđevnog fakulteta obnašao je 1970-72. Bio je prvi rektor Sveučilišta u Rijeci 1973-76.

Josip Uršić, inženjer brodogradnje (Varaždin, 1923 - Zagreb, 1994). Diplomirao je 1951. na Brodograđevnom odjelu Tehničkoga fakulteta, a doktorirao 1978. na FSB-u. Bio je redoviti profesor (1973-93) i dekan fakulteta (1970-72), predstojnik Zavoda za brodogradnju (1973-75) i Katedre za teoriju i čvrstoću broda (1959-61). Osnovao je i opremio laboratorij za brodske konstrukcije, pokrenuo poslijediplomski studij brodogradnje (1965). Rezultate svojih istraživanja objavio je u nizu znanstvenih i stručnih radova, udžbenicima Stabilitet broda (I-II, 1962-64), Plovnost broda (1966) i Črrstoća broda (I-II, 1972-83), a autor je i niza priloga za Pomorsku, Tehnicku i Vojnu enciklopediju. Dobitnik je Republičke nagrade Nikola Tesla 1976. i Nagrade za životno djelo 1988.

Mladen Hudec, inženjer građevinarstva (Slunj, 1924 - Zagreb, 2004). Diplomirao je 1950. na Tehničkom fakultetu u Zagrebu, a doktorirao 1980. na Građevinskom fakultetu u Zagrebu. Od 1951. do 1958. radio je kao asistent na Tehničkom fakultetu u Sarajevu na katedri Statika konstrukcija. Višekratno je studijski boravio u laboratorijima u Zürichu, Münchenu, Liegeu, Delftu, Parizu i Londonu, gdje se upoznao s eksperimentalnim metodama analize naprezanja, ponajprije s fotoelasticimetrijom. Na Katedri za statiku utemeljio je Laboratorij za modelska ispitivanja, a bio je uključen i u konstruiranje fotoelastične aparature i Moiré uređaja za ispitivanje modela ravnih ploča. Provodio je modelska ispitivanja za dimenzioniranje teške generatorske ploče HE Jajce II te za ljuske mornaričkih domova u Šibeniku i Splitu. Tridesetak je godina surađivao i s Biomehaničkom sekcijom Zbora liječnika Hrvatske te Medicinskim i Prirodoslovno-matematičkim fakultetom u području eksperimentalnoga i teorijskoga razmatranja biomehaničkih problema. Zajedno $\mathrm{s}$ profesorom Vasilijem Nikolićem objavio je prvu knjigu iz biomehanike na hrvatskom jeziku: Principi i elementi biomehanike. Napisao je i posebna poglavlja u nekoliko stručnih knjiga. Akademske godine 1970/71. bio je gostujući profesor na Henry Crumb School of Mines Sveučilišta Columbia u New Yorku. Od 1965. na RGN fakultetu Sveučilišta u Zagrebu predaje predmete: Mehanika, Otpornost materijala, Građevinarstvo, Mehanika stijena, a od 1985. i predmet Izgradnja podzemnih prostorija i tunela. Nakon umirovljenja postao je professor emeritus.

Mirko Krpan, brodograđevni inženjer (Drinak kraj Novoga Vinodolskoga, 1924 - Rijeka, 2006). Diplomirao je 1955. na Tehničkom fakultetu u Zagrebu, a doktorirao 1979. na Tehničkom fakultetu u Rijeci. Nakon diplomiranja radio je u Upravi za mornaričko-tehnička istraživanja u Splitu i Predstavništvu pri 
Brodoprojektu Rijeci. Od 1963. na Tehničkom fakultetu u Rijeci u Zavodu za tehničku mehaniku predavao je mehaniku i višu dinamiku. Za redovitoga profesora izabran je 1979. Obnašao je dužnost dekana te prorektora i rektora Sveučilišta u Rijeci. Počasni je član HDM-a. Istraživao je u području mehanike. Pretežan dio znanstvene aktivnosti usmjerio je na otkrivanje novih teorijskih fenomena trenja i njegovih triboloških manifestacija u tehničkoj praksi. Počasno zvanje professora emeritusa dobio je 1997.

Antun Vučetić, inženjer elektrotehnike (Andrijevica, Crna Gora, 1924 - Rijeka, 1988). Diplomirao je 1952. na Tehničkom fakultetu Sveučilišta u Zagrebu, a doktorirao 1966. na tadašnjem SBF-u. Nakon diplomiranja zaposlio se na Katedri za tehničku mehaniku Tehničkoga fakulteta, gdje je 1972. izabran za redovitoga profesora. Na FSB-u je neprekidno radio do odlaska u mirovinu 1984. Ponovno se zaposlio kao redoviti profesor na Fakultetu prometnih znanosti, na kojem je radio sve do smrti. Cijeli svoj radni vijek proveo je na Sveučilištu u Zagrebu, ispreplećući i nadopunjujući nastavu, znanstvenoistraživačku i stručnu djelatnost. Podjednako je dobro poznavao teoriju i tehničku praksu. Poznata su njegova izvrsna rješenja brojnih problema iz strojarske prakse, u kojima je uvijek nalazio duboku fizikalnu vezanost i objašnjenja. Posebno se ističu njegove aktivnosti na interdisciplinarnom planu primjene mehanike: u medicini, stomatologiji, biomehanici, ergonomiji i kriminalistici. U znanstvenom i stručnom opusu uvelike je pridonio području teorije vibracija i dinamike strojeva, posebno razvoju analize i ispitivanja u strojarstvu, brodogradnji, željezničkom i cestovnom prometu te eksploataciji strojeva i uređaja u brojnim industrijskim pogonima. Bio je ugledni član brojnih znanstvenih i stručnih institucija: član Znanstvenoga savjeta međunarodnoga centra za mehaničke znanosti u Udinama, suradnik JAZU, savjetnik Brodarskoga instituta, tvornice Jugoturbina Karlovac, tvornice Rade Končar Zagreb, tvornice Janko Gredelj Zagreb, Instituta za klinička i medicinska istraživanja, Zavoda za elektrostrojarstvo Elektrotehničkoga fakulteta, Zavoda za kriminalistiku i kriminološka vještačenja. Uživao je velik ugled, što potvrđuje velik broj odlikovanja i priznanja. Dobitnik je, među ostalim, Ordena rada sa zlatnim vijencem, Ordena za vojne zasluge sa zlatnim mačevima, Zlatne plakete i Zlatne medalje JAZU i drugih priznanja. Jedan je od osnivača HDM-a 1969. u Zagrebu.

Ivo Petković, inženjer brodogradnje (Split, 1926 - Split, 1984). U Zagrebu je diplomirao 1952. na Tehničkom fakultetu i doktorirao 1966. na Strojarsko-brodograđevnom fakultetu. Nakon diplomiranja zaposlio se 1952. u Brodogradilištu Split. Godine 1961. zaposlio se na Elektrotehničkom fakultetu u Splitu (danas Fakultet elektrotehnike, strojarstva i brodogradnje - FESB), 
odmah nakon njegova osnutka 1960., gdje je držao nastavu iz tehničke mehanike. Za redovitoga profesora bio je izabran 1977. Na FESB-u je bio voditelj Katedre za mehaniku i teoriju broda 1970-79. i istodobno predstojnik Odjela strojarstva i brodogradnje. Bavio se mehanikom, teorijom mehanizama, hidrostatikom broda, plovnošću i stabilnošću broda. Osim na matičnom fakultetu, održavao je nastavu na Vojno-pomorskoj akademiji u Splitu i Građevinskom fakultetu u Zagrebu.

Aleksandar Kiričenko, brodograđevni inženjer (Zagreb, 1927 - Zagreb, 1998). Klasičnu gimnaziju završio je u Zagrebu 1945. Diplomirao je na Brodograđevnom odjelu Tehničkoga fakulteta 1953., a doktorirao je 1978. na Građevinskom fakultetu u Zagrebu. Od 1958. bio je asistent na Građevinskom odsjeku Arhitektonsko-građevinsko-geodetskoga fakulteta (AGG), na kojem je 1985. izabran za redovitoga profesora. Umirovljen je 1997. Napisao je udžbenike Mehanika I., II. i III. Bio je predsjednik Hrvatskog društva za mehaniku 1987-89. Istraživao je u području eksperimentalne mehanike i njezine primjene na tehničke konstrukcije, posebno u području vibracija konstrukcija.

Vilim Korošec, građevinski inženjer (Zagreb, 1928 - Dresden, 1991). U Zagrebu je završio gimnaziju 1946., diplomirao na Građevinskom odsjeku Tehničkoga fakulteta 1954. i doktorirao 1972. na Građevinskom fakultetu, na kojem je izabran za redovitoga profesora 1984. Obnašao je dužnost predstojnika Zavoda za tehničku mehaniku. Državnu nagradu za znanstvenoistraživački rad dobio je 1990. Bio je predsjednik HDM-a.

Milojko Vucelić, strojarski inženjer (Garešnica, 1930 - La Jolla kraj San Diega, California, 2012). Diplomirao je 1954. na SBF-u u Zagrebu radom iz područja tehničke mehanike pod vodstvom profesora Davorina Bazjanca.

Nakon diplomiranja zaposlio se u tvrtki Mercedes-Benz u Stuttgartu, a zatim u Fordu u Kölnu.

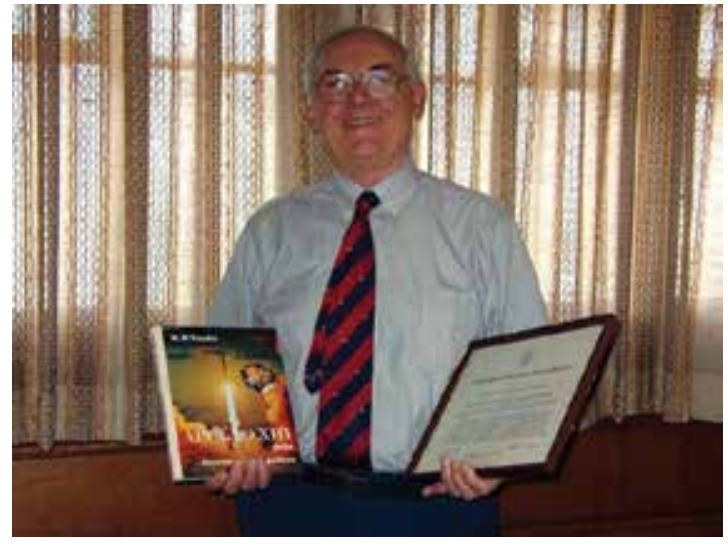

Milojko Vucelić

Stric u Pittsburghu omogućio mu je da se u jesen 1956. useli u SAD, gdje je počeo raditi u tvrtki Cessna Aircraft Company u Wichiti u Kansasu, a zatim u tvrtki North American Aviation u Denveru u kojoj je radio kao projektant uređaja za spašavanje pilota. Budući da je ta tvrtka imala ugovor s NASA-om 
oko izrade svemirske letjelice Apollo, Vucelić je bio uključen u taj program od veljače 1962., analizirajući različite koncepte slijetanja na Mjesec. Poslije je postao menadžer u NASA-inom sjedištu u Houstonu sa zadatkom eliminacije svih mogućih grešaka tijekom leta, pa je od svojih kolega dobio nadimak menadžer za probleme. Svojim najvećim uspjehom smatra misiju Apollo 8 kada je uvjerio rukovodstvo da raketu Saturn V pošalje u misiju oko Mjeseca umjesto još jedne misije u orbiti oko Zemlje. Nakon što je 20. srpnja 1969. misija Apollo 11 uspješno dovela prve ljude na Mjesec, dobio je zadatak proširiti mogućnosti istraživanja Mjeseca iz orbite dodavanjem instrumenata. Na misiji Apollo 13 bio je zadužen za spašavanje astronauta. Primio je poruku zapovjednika Jima Lovella, koji je nakon eksplozije spremnika s kisikom uzviknuo: »Houston, we've had a problem«. Za rješavanje problema i spašavanje posade Apolla 13, predsjednik Nixon odlikovao ga je 1970. Predsjedničkom medaljom slobode (Presidential medal of Freedom). Od 1969. radio je na prilagodavanju Apollo letjelice za spajanje sa Sojuzom (Apollo-Soyuz Test Project, Экспериментальный полёт Аполлон - Союз). U Denveru se oženio njemačkom studenticom Ingeborg Perzl, koja je poslije doktorirala u području eksperimentalne psihologije, i s njom imao sinove Alexandra i Nicholasa. Napisao je dvije knjige o svemirskim istraživanjima koje je izdala Tehnička knjiga u Zagrebu. Održavao je razne znanstvene seminare i napisao mnogo stručnih članaka. Sudjelovanje u svemirskim istraživanjima napustio je 1989. da bi se posvetio poslovnom načinu života. Kupio je tvrtku Ideal Electric Company, koja je imalo 300 zaposlenih i proizvodila veće elektrogeneratore i motore.

Slobodan Janković, strojarski inženjer, (Bruxelles, Belgija, 1932). Diplomirao je 1958. na Vojnoj politehnici u Bruxellesu, a doktorirao 1968. u području mehanike leta na Mašinskom fakultetu u Beogradu. Od osnivanja Vojno-tehničke akademije u Zagrebu 1967. bio je načelnik združenih katedara naoružanja, raketne tehnike i automatskoga upravljanja. Na Mašinski fakultet u Beogradu prešao je 1973. gdje je predavao predmete Dinamika leta projektila i Aerodinamika projektila i surađivao s Vojno-tehničkim Institutom na aerodinamičkom projektu vođene rakete zrak-zemlja. Po završetku projekta vratio se 1984. u Zagreb na Visoku vojno-tehničku školu, gdje je predavao Aerodinamiku i Mehaniku leta i vodio katedru raketne tehnike. Surađivo je s vojnom industrijom (Pretis, Energoinvest, Makpetrol i dr.) i s Hrvatskim meteorološkim zavodom na problemima protugradne obrane kao stalni vanjski suradnik zavoda. Bio je ekspert ministarstva obrane Jugoslavije za probleme aerodinamike i mehanike leta. Sudjelovao je kao jedini pozvan profesor iz istočnih zemalja na savjetovanju »European Forum on Ballistics of Projectiles« u Saint Louisu u travnju 2000. Predavao je mehaniku leta zrakoplova i mehaniku leta projektila na FSB-u u Zagrebu. 
Vatroslav Grubišić, inženjer strojarstva (Solin, 1933). Diplomirao je 1958. na SBF-u u Zagrebu 1958., a doktorirao 1970. na Tehničkom sveučilištu u Münchenu. Od 1961. radio u Institutu za pogonsku čvrstoću Fraunhofer u Darmstadtu, gdje je bio voditelj Odjela za analizu naprezanja i provjeru čvrstoće 1970-96. te bio zamjenik direktora Instituta 1978-86. Od umirovljenja 1996. neovisni je konzultant, sudski vještak i direktor biroa Technical Consulting u Georgenhausenu. Predavao je kao redoviti profesor na FESB-u u Splitu te na FSB-u u Zagrebu, na tehničkim fakultetima u Hefeiju (Kina) i u Padovi (Italija). Bavi se istraživanjem ponašanja i vijeka trajanja materijala i konstrukcija pod realnim uvjetima opterećenja. Autor je 20 patentiranih inovacija vezanih uz ispitivanje kotača vozila, simulaciju njihova opterećenja u vožnji te ispitivanje dinamičke izdržljivosti. Dobitnik je Fraunhoferove nagrade 1986. i dopisni član Hrvatske akademije znanosti i umjetnosti (HAZU) od 2008 .

Krešimir Herman, građevinski inženjer (Banja Luka, 1934 - Zagreb, 2017). Diplomirao je 1959. i doktorirao 1974. na AGG fakultetu Sveučilišta u Zagrebu. Godine 1962., još prije diplomiranja, radio je na gradilištu HE Peruča. Poslije diplomiranja radio je u Industrogradnji. Na poziv profesora Z. Kostrenčića i Zlatka Modora došao je na mjesto asistenta u Zavodu za ispitivanje gradiva AGG fakulteta, gdje je 1986. izabran za redovitoga profesora. Umirovljen je 2004. Izvodio je prototipska modelska ispitivanja mnogih konstrukcija, primjerice stadiona u Splitu i vodotornja u Novoj Gradiški. Izvodio je dinamička istraživanja temelja turbogeneratora mnogih termoelektrana i hidroelektrana. Objavio je knjigu Teorija elastičnosti i više znanstvenih radova.

Ivan Heidl, strojarski inženjer (Zagreb, 1934 - Zagreb, 2012). Diplomirao je 1960. na Strojarsko-brodograđevnom fakultetu u Zagrebu, a doktorirao 1979. na Fakultetu strojarstva i brodogradnje u Zagrebu. Nakon diplomiranja radio je dvije godine u poduzeću Rade Končar. Od 1963. do umirovljenja 2004. radio je na FSB-u, gdje je 1985. izabran za redovitoga profesora. Istraživao je u području eksperimentalne analize naprezanja i području analize ljusaka s diskontinuitetima. Napisao je prilog u Tehničkoj enciklopediji o tenzometriji. Jedan je od osnivača HDM-a, u kojem je obnašao dužnost tajnika.

Stjepan Jecić, inženjer elektrotehnike (Vinkovci, 1934). Diplomirao je na Elektrotehničkom fakultetu u Zagrebu 1959., a doktorirao 1972. na FSB-u, gdje je radio od 1963. do umirovljenja 2005. te bio redoviti profesor od 1982. i dekan (1992-94). Bio je osnivač i voditelj Katedre za eksperimentalnu mehaniku 1997. U dva je navrata bio gostujući profesor na Sveučilištu u Münchenu. Istraživao je u području eksperimentalne analize naprezanja i deformacija, zaslužan je za razvoj više izvornih postupaka. Bio je voditelj međunarodnih 
znanstvenih projekata u suradnji sa sveučilištima u Münchenu, Kijevu, Beču i Budimpešti te s Austrijskim istraživačkim centrom u Seibersdorfu. Autor je pet udžbenika i monografija. Od 2000. redoviti je član HAZU i tajnik Razreda za tehničke znanosti od 2011. Jedan je od osnivača Hrvatskoga društva za mehaniku, kojemu je bio predsjednik u dva mandata. Suosnivač je međunarodnog društva Danubia Adria Society. Dobitnik je Republičke nagrade za znanstvenoistraživački rad »Nikola Tesla«1979. i Državne nagrade za životno djelo 2005. Nositelj je počasnoga zvanja professor emeritus.

Osman Muftić, inženjer strojarstva (Sarajevo, 1934 - Zagreb, 2010). Diplomirao 1959., a doktorirao 1972. na SBF-u u Zagrebu. Nakon diplomiranja radio je u projektnom birou Instalacije u Zagrebu, a od 1963. do umirovljenja djelovao je na FSB-u, gdje je izabran za redovitoga profesora 1982. i bio dekan 1989-90. Osim na matičnom fakultetu, izvodio je nastavu na više fakulteta u Zagrebu. Bio je i dekan na Grafičkom fakultetu 1982-84. Kao gostujući profesor boravio je na Sveučilištu Garyounisu u Benghaziju i na Sveučilištu u Teheranu. Osnivač je Katedre za biomehaniku i ergonomiju te jedan od osnivača Laboratorija za dinamiku strojeva i mehanizama. Uveo je u nastavu kolegije Biomehanika i Ergonomija. Istraživao je u području mehanike, biomehanike i ergonomije. Autor je brojnih znanstvenih i stručnih radova te pet monografija i udžbenika. Bio je redoviti član Medicinske akademije i Akademije tehničkih znanosti Hrvatske (HATZ), kojoj je i suosnivač. Bio je prvi ministar znanosti nakon osamostaljenja Republike Hrvatske i veleposlanik u Iranu 1993-96. Dobitnik je Nagrade za znanstveni rad Nikola Tesla 1989., Državne nagrade za životno djelo 1999. te nositelj počasnoga zvanja professor emeritus Sveučilišta u Zagrebu 2005. Jedan je od osnivača HDM-a 1969. u Zagrebu.

Mirko Butković, strojarski inženjer (Karlovac, 1936). Diplomirao je 1961. na SBF-u u Zagrebu, a doktorirao 1976. na FSB-u u Zagrebu. Nakon diplomiranja zaposlio se u tadašnjoj tvornici Jugoturbina i ostao vezan uz nju, odnosno uz njezine tvrtke sljednice Enin, ABB i ALSTOM, sve do 2003. U Jugoturbini je u početku radio kao razvojni inženjer, a poslije je obavljao razne upravne dužnosti: bio je direktor razvoja, podpredsjednik korporacije, direktor instituta i rukovoditelj odjela mehaničkoga integriteta. Paralelno sa zaposlenjem u Jugoturbini sudjeluje u nastavi i istraživanju na visokoškolskim ustanovama: na Visokoj tehničkoj strojarskoj školi (VTSŠ) u Karlovcu 1961-84., na FSB-u u Zagrebu 1984-97., na Tehničkom fakultetu u Rijeci 1988-2006., na Veleučilištu u Karlovcu 1997-2006., na kojem je obnašao dužnost rektora 1997-2005. Područje njegova zanimanja i istraživanja su: dinamika strojeva, prigušenje materijala i vijek trajanja strojeva. U tom je području objavio veći broj znanstvenih radova i jednu knjigu. Redoviti je član Akademije tehničkih znanosti Hrvatske. Bio je zastupnik u Županijskom domu Sabora 1993-97. 
Milutin Anđelić, inženjer građevinarstva (Pljevlja, Crna Gora, 1936). Diplomirao je 1963. i doktorirao 1972. na Građevinskom fakultetu u Zagrebu. Nakon diplomiranja radio je u građevinskom poduzeću Tehnika u Zagrebu. Na Građevinskom fakultetu u Zagrebu zaposlio se 1964. na Katedri za građevnu statiku i betonske konstrukcije. Redoviti profesor postao je 1985. Obavljao je dužnost dekana 1989-91. Objavio je više znanstvenih i stručnih radova iz područja tehničke mehanike i nosivih konstrukcija. Napisao je udžbenik Građevna statika II (2005). Dobitnik je Europske nagrade za čelične konstrukcije (European Convention for Constructional Steelwork) za projekt sportske dvorane Cibona u Zagrebu. Postao je professor emeritus 2008.

Vicko Šimić, inženjer građevinarstva (Tučepi, 1937). Diplomirao je 1962. na Građevinskom odsjeku AGG fakulteta. Doktorirao je 1974. na Građevinskom fakultetu (GF) u Zagrebu. Nakon diplomiranja kratko je radio u poduzeću Jugomontaža u Zagrebu. Od 1963. radi na GF-u u Zagrebu na kojem je 1986. izabran za redovitoga profesora i bio prodekan 1979-83. Bio je predsjednik HDM-a 1994-96. i član predsjedništva JDM-a 1986-88. Objavio je dva sveučilišna udžbenika i više skrpta i priloga u tehničkim priručnicima. Istraživao je u području primjene analitičkih funkcija u analizi naprezanja i u području eksperimentalne analize naprezanja.

Josip Dvornik, inženjer građevinarstva (Zagreb, 1938). Školovao se u Zagrebu, gdje je na GF-u diplomirao 1963. te doktorirao 1972. te radio do 1965., potom kao projektant u Konstrukcijskom birou građevinske industrije (do 1968.), ponovno na Građevinskom fakultetu do 1971., u Institutu građevinarstva Hrvatske do 1977. te naposljetku na Građevinskom fakultetu, gdje je postao redoviti profesor 1986. i do umirovljenja 2008. radio u Zavodu za tehničku mehaniku. Predavao je kolegije Stabilnost i dinamika konstrukcija i Plošni nosači. Bavio se proračunom nosivih konstrukcija numeričkim metodama te se istaknuo kao projektant šatorastih konstrukcija. Dobitnik je godišnje državne Nagrade »Nikola Tesla« 1986. te nositelj zvanja professor emeritus od 2008

Ivo Alfirević, strojarski inženjer (Split, 1939). Diplomirao je 1962. na SBF-u u Zagrebu, magistrirao 1968. na Ilinois Institute of Technology u Chicagu i doktorirao 1972. na FSB-u u Zagrebu. Nakon diplomiranja radio je dvije godine u poduzeću Dalmacija-cement u Splitu, a od 1965. do umirovljenja stalno je zaposlen na FSB-u, gdje je 1983. izabran za redovitoga profesora. Prvih dvadeset godina istraživao u području eksperimentalne mehanike gdje je postigao značajne rezultate. Zajedno s mentorom J. W. Dallyjem otkrio je i objasnio učinak razlike Poissonovih faktora obloge i modela. Razradio je teoriju primjene izotropne fotoelastične obloge na ortotropnim modelima, definirao je 
pojam efektivnoga faktora koncentracije naprezanja za ortotropne konstrukcije. Sljedećih dvadeset godina istraživao u području mehanike kontinuuma i tenzorskoga računa. Razradio je opći tenzorski pristup kriterijima tečenja i loma materija. Pridonio je razvoju hrvatskoga tehničkoga nazivlja i uvođenju SI sustava u nastavu na FSB-u. Posljednjih deset godina piše i istražuje u području povijesti i filozofije tehničkih znanosti, a posebno mehanike. Objavio je deset sveučilišnih udžbenika, dvije monografije i veći broj priloga u Tehničkoj enciklopediji i tehničkim priručnicima. Obnašao je dužnosti predstojnika Zavoda, prodekana i dekana FSB-a. Jedan je od osnivača HDM-a u kojemu je bio prvi tajnik i predsjednik u tri mandata, a od 2006. počasni član. Obavljao je u dva mandata dužnost potpredsjednika JDM-a. Bio je predstavnik je HDM-a u IUTAMU-u (International Union of Theoretical and Applied Mechanics) i predstavnik HDM-a u Znanstvenom vijeću CISM-a u Udinama 1995-2005. Osnivač je i glavni urednik časopisa Transactions of FAMENA i član uredništva još pet znanstvenih časopisa. Član je i pokretač međunarodnoga odbora Danubia-Adria Committee. Član je Akademije tehničkih znanosti Hrvatske. Za svoj rad dobio je brojne nagrade i priznanja, među ostalim Nagradu »Nikola Tesla« 1993., Državnu nagradu za životno djelo 2009. te odličje Red Danice hrvatske. Za profesora emeritusa Sveučilišta u Zagrebu izabran je 2010.

Ivo Senjanović, inženjer brodogradnje (Split, 1940). Diplomirao je 1967. i doktorirao 1970. na FSB-u u Zagrebu. Nakon diplomiranja radio na Brodarskom institutu u Zagrebu, a od 1969. na FSB-u gdje je izabran za redovitoga profesora 1983. Obnašao je dužnosti predstojnika Zavoda za brodogradnju i pomorsku tehniku i voditelja Katedre za konstrukciju plovnih objekata. Uveo je kolegije Teorija ploča i ljuski i Vibracije broda. Radio je kao gostujući istraživač na Kalifornijskom sveučilištu u Berkeleyu 1973. te u konzultantskoj tvrtki Det norske Veritas u Oslu 1974-75. Autor je mnogobrojnih znanstvenih radova te šest monografija. Dobitnik je Nagrade »Nikola Tesla« 1974. i Državne nagrade za životno djelo 2009. Redoviti je član HAZU od 2002.

Frane Damjanić, inženjer građevinarstva (Split, 1944 - Ljubljana, 1998). Diplomirao je 1968. na GF-u u Zagrebu, a doktorirao 1984. na Sveučilišsu u Walesu, u Swanseaju, pod mentorstvom D.R.J. Owena u okruženju koje je bilo europski vrh u području numeričkoga modeliranja konstrukcija. Nakon diplomiranja pet je godina radio u splitskom »Konstruktoru«, a zatim prelazi u Građevinski institut na Fakultetu građevinskih znanosti Sveučilišta u Splitu. Uspješno je vodio međunarodne projekte (TEMPUS, PECO, ALIS). Redovni je profesor u Splitu i od 1987. na Fakultetu za arhitekturu, građevinarstvo i geodeziju u Ljubljani te gostujući profesor na Sveučilištu u Padovi. Jedan je 
od osnivača časopisa International fournal for Engineering Modelling i član uredništva dvaju inozemnih međunarodnih časopisa. Uspješan je organizator međunarodnih konferencija na kojima okuplja vrhunske svjetske znanstvenike iz područja numeričkoga modeliranja konstrukcija. Istraživao je u području računalne mehanike, nelinearne i neelastične analize konstrukcija, eksperimentalne mehanike, nelinearnih numeričkih modeliranja za provođenje topline, za dinamičku/potresnu analizu armirano betonskih konstrukcija, za simulaciju industrijske proizvodnje staklenih i plastičnih proizvoda, za proizvodnju automobilskih guma, za termodinamičku analizu motora s unutarnjim izgaranjem, za predviđanja gibanja klizišta, za analizu konstrukcija ljusaka od kompozitnih plastičnih materijala, te $u$ području biomehanike. Posebno treba istaknuti atraktivnu studiju toplinskih utjecaja na okolno tlo i podmorje Eurotunela ispod kanala La Manche.

Nenad Bićanić, inženjer građevinarstva (Zagreb, 1945 - Veli Lošinj, 2016). Diplomirao je 1968. na GF-u u Zagrebu, doktorirao 1978. na Sveučilištu u Walesu u Swanseaju. Nakon diplomiranja ostao je na GF-u u Zagrebu, gdje je 1985. izabran za redovitoga profesora. Od 1985. do 1994. bio je predavač na Sveučilištu u Walesu, a od 1994. zaposlen je kao profesor na Sveučilištu u Glasgowu, gdje je od 1997. do 2001. bio predstojnik Građevinskoga odjela. Od 2007. do 2011. bio je direktor Zajedničkoga istraživačkog instituta za mehaniku materijala i struktura te bioinženjering.

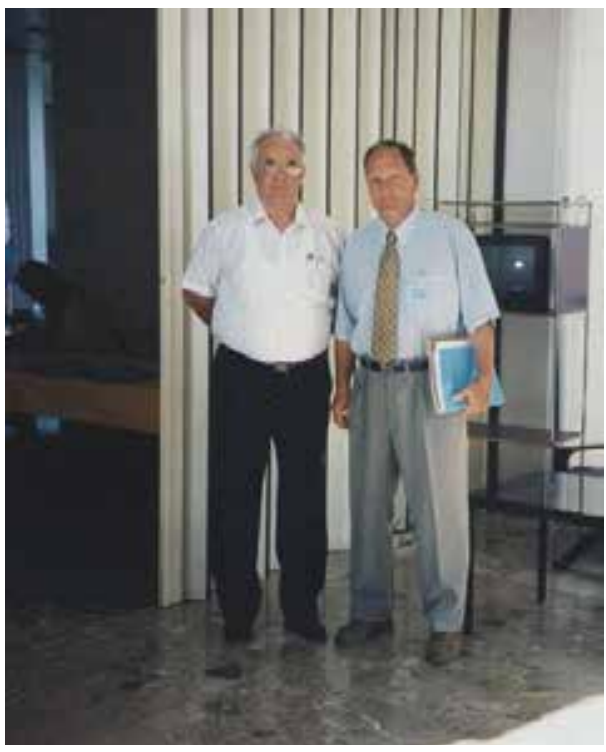

Profesori Alfirević i Bićanić u Supetru na Braču

Profesor Bićanić svojim je radovima znatno pridonio razvoju građevinarstva i računalne mehanike i odgojio brojne mlade znanstvenike, među kojima i nekoliko iz Hrvatske. Područje njegova rada bile su metode konačnih elemenata, diskretnih elemenata i metoda diskontinuiranih deformacija, statika i dinamika konstrukcija, konstitutivni modeli krhkih materijala, modeliranje ponašanja betona pri naglim opterećenjima i velikim temperaturama.

Bio je organizator dugogodišnje serije međunarodnih konferencija o modeliranju ponašanja betona i betonskih konstrukcija te jedan od osnivača i bivši 
predsjednik Udruge za računalnu mehaniku u inženjerstvu (Association for Computational Mechanics in Engineering). Urednik je međunarodnog časopisa International fournal of Computers $\mathcal{E}$ Concrete za Europu. Dopisni je član HAZU od 2010. i professor emeritus Sveučilišta u Glasgowu od 2011. Dok je radio u Veliku Britaniji, intenzivno je surađivao s hrvatskim znanstvenicima i stručnjacima, sudjelujući u poslijediplomskoj nastavi, u realizaciji dva TEMPUS-ova projekta i radom u Hrvatskom društvu za mehaniku, koje ga je izabralo za svojega počasnoga člana 2004.

Radoslav Pavazza, inženjer brodogradnje (Split, 1945). Diplomirao je 1972. na Mašinskom fakultetu u Beogradu i doktorirao 1991. na FSB-u u Zagrebu. Nakon diplomiranja zaposlio se u Brodogradilištu Split. Na FESB u Splitu prelazi 1974. na Katedru za nauku o čvrstoći. Od 1984. do 1985. radio je u Jugoslavenskom registru brodova u Splitu. Nakon toga vraća se na FESB, gdje radi do umirovljenja 2015. Za redovitoga profesora izabran je 2003. Nakon umirovljenja promoviran je u zvanje professora emeritusa 2016. Istraživao je i objavljivao znanstvene radove u područjima mehanike krutih i deformabilnih tijela, teorije elastičnosti, tankosjene konstrukcije, čvrstoće broda. Važne rezultate postigao je $u$ analizi tankostjenih štapova na elastičnoj podlozi. Objavio je dva sveučilišna udžbenika i jednu monografiju. Dobitnik je priznanja Plaketa Sveučilišta u Splitu za izniman doprinos razvoju Sveučilišta u Splitu 2015. i Elsevier Rewier Recognition of Engineering Structures 2015.

Želimir Šimunić, inženjer građevinarstva (Zagreb, 1946 - Zagreb, 2018). Diplomirao je 1970. i doktorirao 1990. na GF-u u Zagrebu. Nakon diplomiranja kratko je bio zaposlen u IGH-u u Zagrebu. Od 1972. do 1974. radi u firmi Ostrowski u Offenbachu u Njemačkoj. Početkom 1975. dolazi na GF u Zagrebu, Zavod za tehničku mehaniku, gdje je 2004. izabran za redovitoga profesora. Kao stipendist DAAD-a usavršava se 1977/78. na Institutu za preradu polimera $\mathrm{u}$ Aachenu. Istražuje u području primjene polimernih materijala u graditeljstvu. Objavio je dvije knjige: Polimeri u graditeljstvu (2006) i Elastomerni ležajevi (2007).

Vedran Žanić, inženjer brodogradnje (Split, 1946). Diplomirao je 1971. i doktorirao 1980. na FSB-u u Zagrebu. Nakon diplomiranja radi na Brodarskom institutu u Zagrebu. Boravio je na specijalizaciji na Kalifornijskom sveučilištu u Berkeleyu 1974-75. Zaposlio se 1977. na FSB-u, gdje je izabran za redovitoga profesora 1997. Bio je predstojnik Zavoda za brodogradnju 1982-84. Jedan je od osnivača studija zrakoplovstva. Bio je gostujući predavač na sveučilištima u Cambridgeu, Berkeleyju, Bostonu, New Yorku, Sydneyju i Glasgowu. Istraživao je u području numeričkih metoda u analizi i projektiranju konstrukcija, vodio je više hrvatskih i međunarodnih znanstvenih projekata te bio aktivan u radu više vodećih strukovnih udruga. Dobitnik je Nagrade »Nikola Tesla« 1986. Član je suradnik HAZU od 1994. 
Nikola Vranković, inženjer strojarstva (Zagreb, 1947). Diplomirao je 1971. i doktorirao 1984. na FSB-u u Zagrebu. Nakon diplomiranja zaposlio se na Katedri za mehaniku i nauku o čvrstoći FSB-a gdje je 2001. izabran za redovitoga profesora. Njegova znanstvena djelatnost odvija se u području numeričke mehanike. Obnašao je dužnost predstojnika Zavoda za mehaničke konstrukcije i voditelja Katedre za dinamiku mehaničkih sustava. U Hrvatskom društvu za teoriju strojeva i mehanizama obavlja dužnost tajnika od 2002. Bio je predsjednik Izvršnoga odbora Central European Association for Computational Mechanics (CEACM) koji okuplja znanstvenike iz sedam srednjoeuropskih zemalja od 1995., a od 1999. obnaša dužnost dopredsjednika CEACM-a.

Milenko Stegić, inženjer strojarstva (Drugovići, BiH, 1948). Diplomirao je 1971. i doktorirao 1984. na FSB-u u Zagrebu. Nakon diplomiranja zaposlio se 1972. na Katedri za mehaniku i nauku o čvrstoći FSB-a gdje je 2000. izabran za redovitoga profesora. Usavršavao se 1977. u području dinamike i pogonske čvrstoće na Tehničkom sveučilištu u Dresdenu. Kao stipendist DAAD-a boravio je 1979/80. na Sveučilištu u Hannoveru u Institutu za mjerenje u strojarstvu i Institutu za mehaniku, a 1988/89. na Technische Hochschule Darmstadt u Institutu za dinamiku strojeva. Istražuje u području dinamike i vibracija strojarskih konstrukcija. Napisao je dva sveučilišna udžbenika. Obnašao je dužnost predsjednika Hrvatskog društva za teoriju strojeva i mehanizama u više navrata.

Ante Mihanović, inženjer građevinarstva (Donje Sitno kraj Splita, 1948). Diplomirao je 1972. i doktorirao 1981. na GF-u u Zagrebu. Od jeseni 1972. godine neprekidno je zaposlen na Fakultetu građevinarstva, arhitekture i geodezije u Splitu. U trajno zvanje redovitoga profesora potvrđen je 2001. Utemeljitelj je te glavni i odgovorni urednik međunarodnog časopisa Engineering modelling od 1987. do danas. Objavio je više od sto znanstvenih radova. Autor je i suautor pet knjiga. Uže područje znanstvenoga djelovanja numeričko je modeliranje mehanike građevinskih konstrukcija. Nositelj je deset patentiranih izuma. Obavljao je dužnosti predstojnika zavoda, prodekana i dekana. Nagrađen je 2007. Nagradom za razvoj Sveučilišta u Splitu. Član je suradnik HAZU i redoviti član HATZ-a.

Franjo Matejiček, inženjer strojarstva (Štivica kraj Staroga Petrovoga Sela, 1949). Diplomirao je 1975. i doktorirao 1989. godine na FSB-u u Zagrebu. Stalno je zaposlen na SF-u u Slavonskom Brodu od 1979., gdje je 2000. izabran za redovitoga profesora. Kao gostujući znanstvenik boravio je $u$ dva navrata $u$ inozemstvu na Hochschule Bremen. Objavio je tri sveučilišna udžbenika. Radio je na razvoju numeričkih i eksperimentalnih metoda teorije elastičnosti, teorije plastičnosti i mehanike loma. Član je HDM-a i Europskoga udruženja 
za integritet konstrukcija (ESIS - European Society of Integrity of Structures). Bio je predsjednik HDM-a u dva mandata. Član je HATZ-a.

Dragan Pustaić, strojarski inženjer, (Orubica kraj Davora, 1950). Diplomirao je 1974. i doktorirao 1990. na FSB-u u Zagrebu. Nakon diplomiranja tri je godine je radio u Tvornici generatora »Rade Končar« u Zagrebu. Od 1979. do umirovljenja 2015. bio je stalno zaposlen na FSB-u Zagrebu, gdje je 2001. izabran za redovitoga profesora. Suautor je tri sveučilišna udžbenika i autor nekoliko priloga u priručnicima. Istraživao je probleme vezane uz teoriju plastičnosti i elasto-plastičnu mehaniku loma.

Josip Brnić, inženjer strojarstva (Sv. Ivanu na Krku, 1951). Diplomirao je 1976., a doktorirao 1988. na Tehničkom fakultet u Rijeci. Nakon diplomiranja zaposlio su u Brodoprojektu. Od 1978. radi na Tehničkom fakultetu u Rijeci. Predavao je više predmeta iz područja tehničke mehanike, od statike do teorije elastičnosti i teorije plastičnosti. Za redovitoga profesora izabran je 1996. Njegova se znanstvena istraživanja odnose na mehaniku čvrstih tijela i mogu se svrstati u dvije skupine: prva se odnosi na numeričku analizu konstrukcija, a druga na eksperimentalnu analizu ponašanja materijala pri sniženim i povišenim temperaturama. Samostalno ili u suautorstvu objavio je oko 300 znanstvenih radova i veći broj stručnih radova. Napisao je 11 knjiga, među kojima se ističe posljednja, Analysis of Engineering Structures and Material Behavior (2018). Napisao je velik broj poglavlja u knjigama i priručnicima. Obnašao je brojne upravne dužnosti, među ostalima predstojnika zavoda, dekana Tehničkoga fakulteta u dva mandata i rektora Sveučilišta u Rijeci. Surađivao je s brojnim inozemnim sveučilištima, među kojima se ističu ona u Kini. Bio je honorarni profesor na Henan Polytechnic University, profesor savjetnik na Harbin Institute of Technology, gostujući profesor na Huazhong University of Science and Technology i na Shenyang University of Technology. Za svoj plodan i uspješan rad dobio je 13 nagrada i priznanja. Član je suradnik HAZU, redoviti član Akademije tehničkih znanosti Hrvatske i član suradnik International Academy of Engineering, Moskva.

Pavao Marović, inženjer građevinarstva (Split, 1954). Diplomirao je 1977. i doktorirao 1987. na GF-u u Zagrebu. Nakon diplomiranja zaposlio se na Građevinskom fakultetu Sveučilišta u Splitu (danas Fakultet građevinarstva, arhitekture i geodezije), gdje je 1966. izabran u redovitoga profesora. Jedan je od pokretača i glavni urednik (1988-2014) međunarodnoga časopisa International fournal for Engineering Modelling. U suautorstvu objavio je jedan sveučilišni udžbenik. Istražuje u području računalne mehanike, numeričkih metoda, nelinearne i neelastične analize konstrukcija i eksperimentalne mehanike primijenjene na sve vrste građevinskih konstrukcija. Obnašao je dužnost predsjednika HDM-a. 
Jurica Sorić, inženjer strojarstva (Trogir, 1954). Diplomirao je 1978. i doktorirao 1989. na FSB-u u Zagrebu. Nakon diplome radio je u Tvornici generatora »Rade Končar« u Zagrebu. Od 1980. radi na FSB-u u Zagrebu, gdje je izabran za redovitog profesora 2000. Kao stipendist zaklada DAAD-a, Alexander von Humboldt i zaklade Fulbright usavršavao se i gostovao u više navrata na sveučilištima u Njemačkoj i SAD-u. Bavi se nelinearnom analizom ljuskastih konstrukcija, razvojem numeričkih algoritama u metodi konačnih elemenata i numeričkih bezmrežnih metoda te modeliranjem procesa elastoplastičnih deformacija i cikličke plastičnosti. Dobitnik je Državne nagrade za znanost 1999. Napisao je dva sveučilišna udžbenika. Redoviti je član Akademije tehničkih znanosti i član suradnik Hrvatske akademije znanosti i umjetnosti od 2008. Obnašao je dužnost predsjednika HDM-a.

Joško Ožbolt, inženjer građevinarstva (Zagrebu, 1955). Diplomirao je 1978. i doktorirao 1982. na GF-u u Zagrebu. Postdoktorsku specijalizaciju dovršio je 1995. na Sveučilištu u Stuttgartu, Nakon diplomiranja zaposlio se kao asistent na GF-u u Zagrebu. Bio je na usavršavanju u TNO (Institut za primijenjena istraživanja u znanosti) u Nizozemskoj 1980-81. i na Northwestern Universityju, SAD. Od 1989. zaposlen je na Sveučilištu u Stuttgartu, gdje je 2010. izabran za redovitoga profesora. Bio je gostujući profesor na sveučilištima u Rimu, Rijeci i Zagrebu. Istražuje u područjima mehanike loma, modeliranja materijala, spregnutih hidro-termo-mehaničkih problema i nelinearne računalne mehanike. Član je uređivačkih odbora pet znanstvenih časopisa u području računalnih postupaka u inženjerstvu.

Željan Lozina, inženjer strojarstva (Sarajevo, 1956). Diplomirao je 1980. na FESB-u u Splitu, a doktorirao 1989. na FSB-u u Zagrebu. Nakon diplomiranja zaposlio se na FESB-u u Splitu, gdje je 2000. izabran za redovitoga profesora. Područja njegova istraživanja su dinamika i vibracije. Koristi numeričke metode i modeliranje: dinamika tijela, inverzna analiza, algoritmi, eksperimentalna i numerička analiza vibracija. Osnovao je Laboratorij za vibracije i buku na FESB-u u Splitu. Napisao je tri sveučilišna udžbenika.

Damir Semenski, strojarski inženjer (Zagreb, 1959). Diplomirao je 1983. i doktorirao 1995. na FSB-u. Nakon diplomiranja zaposlio se u tvornici Končar - Transformatori. Od 1985. radi na FSB-u, gdje je 2005. izabran za redovitoga profesora. Njegov znanstveni rad iz područja eksperimentalne mehanike i mehanike loma doprinos je razvoju analitičkih, numeričkih i eksperimentalnih metoda za primjenu fotoelasticimetrije i kaustike za ispitivanja mehanički izotropnih i anizotropnih materijala. Boravio je u više navrata u inozemstvu: 1991. u SAD-u na Florida State University u Tallahasseeju, 1993. u Austriji na Technische Universität Wien - Institut für Mechanik, a 1994. imao je potpo- 
ru francuske fondacije Robert Schumann za istraživanja u Republici Hrvatskoj. Školske godine 1998/99., uz potporu Fulbrightove stipendije, ostvaruje znanstveno-istraživački program u SAD-u na CALTECH-u u Pasadeni. Dobitnik je Državne nagrade za znanost 1998. Autor je dvaju sveučilišnih udžbenika.

Ivica Kožar, inženjer građevinarstva (Opatija, 1959). Diplomirao je 1983. na Građevinskom fakultetu u Rijeci. Doktorirao je 1991. na GF-u u Zagrebu. Usavršavao se na École polytechnique fédérale de Lausanne i na Universität Stuttgart, Institut für Werkstofe im Bauwesen. Nakon diplomiranja zaposlio se na Građevinskom fakultetu u Rijeci gdje je 2002. izabran za redovitog profesora. Istražuje u području računalno modeliranje konstrukcija i materijala, određivanje parametara modela i inverzno modeliranje te modeliranje širenja zvuka u urbanom okolišu. Pročelnik je Zavoda za računalno modeliranje materijala i konstrukcija GF u Rijeci. Bio je predsjednik HDM-a. Član je uredničkoga odbora međunarodnoga časopisa Coupled Systems Mechanics koji izlazi u Južnoj Koreji.

Gordan Jelenić, inženjer građevinarstva (Rijeka, 1962). Diplomirao je 1986. na Građevinskom fakultetu u Rijeci. Doktorirao je 1993. na Univerzi v Ljubljani, Fakulteta za gradbeništvo in geodezijo. Nakon diplomiranja zaposlio se u poduzeću Građevno-projektni zavod u Rijeci gdje je radio do 1990. Potom do 2004. radio i istraživao na sveučilištima: Univerza v Ljubljani, Fakulteta za gradbeništvo in geodezijo i Imperial College London, Department of Aeronautics te $u$ poduzeću LUSAS Ltd, Kingston-upon-Thames, u velikoj Britaniji. Od 2000. nastavnik je na Građevinskom fakultetu u Rijeci gdje je 2013. izabran za redovitoga profesora. Područja njegova istraživanja su: nelinearna računska mehanika, metoda konačnih elemenata i numerička integracije jednadžbi kretanja s posebnim naglaskom na probleme s velikim prostornim rotacijama. Član je uredništva časopisa fournal of Structural Mechanics, European fournal of Computational Mechanics i Engineering Review.

Goran Turkalj, inženjer strojarstva (Rijeka, 1965). Diplomirao je 1990. i doktorirao 2000. na Tehničkome fakultetu Sveučilišta u Rijeci. Nakon diplomiranja radi u Tvornici traktora i motora, a zatim na Hrvatskim željeznicama. Početkom 1993. zaposlio se na Tehničkome fakultetu Sveučilišta u Rijeci u Zavodu za tehničku mehaniku. Redoviti profesor u trajnom zvanju u istom zavodu postao je 2012. Dužnost dekana Tehničkoga fakulteta obnašao je 2010-16., a 2016-17. i dužnost prorektora Sveučilišta u Rijeci. Bavio se istraživanjima i razvojem numeričkih modela u području mehanike konstrukcija, a koji tematikom obuhvaćaju stabilnost i optimizaciju okvirnih konstrukcija. Tijekom zadnjih godina intenzivno se bavi razvojem konačno-elementnih 
formulacija za analizu nelinearnoga kvazistatičkoga odziva metalnih i kompozitnih grednih konstrukcija s polukrutim spojevima u režimu velikih rotacija, kao i eksperimentalnom analizom ponašanja čeličnih konstrukcijskih materijala na povišenim temperaturama. Objavio je više od sto znanstvenih radova. Suautor je dviju knjiga i pet poglavlja u knjigama, a izradio je i tridesetak stručnih radova. Održao je i više pozvanih predavanja. Dobitnik je Godišnje državne nagrade za znanost 2005. i Nagrade Zaklade Sveučilišta u Rijeci. Predstavnik je HDM-a u IUTAM-u (International Union of Theoretical and Applied Mechanics). Kao hrvatskoga branitelja Predsjednik Republike Hrvatske odlikovao ga je medaljom Oluja.

Zdenko Tonković, inženjer strojarstva (Sisak, 1966). Diplomirao je 1991. i doktorirao 1998. na FSB-u u Zagrebu. Nakon diplomiranja ostao je raditi na FSB-u gdje je 2010. izabran za redovitoga profesora. Sudjelovao je na brojnim znanstvenim projektima u području razvoja i napredne primjene numeričkih algoritama u metodi konačnih elemenata, razvoja modela oštećenja za probleme mehanike loma, numeričkoga modeliranja termo i cikličke plastičnosti metala, procjene cjelovitosti konstrukcija te numeričkoga modeliranja akumuliranja oštećenja u kortikalnom koštanom tkivu. U posljednje vrijeme njegovo istraživanje usmjereno je na više-razinsko modeliranje procesa deformiranja heterogenih materijala temeljeno na homogenizacijskim metodama te na modeliranje prijelaza s atomističkog modela na makro razinu. Objavio je u suautorstvu tri knjige. Dobitnik je Državne nagrade za znanost za 2008. Član je HATZ-a.Član je uredništva Transactions of FAMENA. U tri mandata bio je tajnik Hrvatskog društva za mehaniku. Od 2002. voditelj je Laboratorija za numeričku mehaniku.

Lovre Krstulović-Opara, strojarski inženjer (Split, 1967). Diplomirao je 1994. na FSB-u u Zagrebu, a doktorirao 2000. na Institutu za građevinsku i numeričku mehaniku Sveučilišta u Hannoveru. Nakon diplomiranja zaposlio se na Katedri za mehaniku i nauku o čvrstoći FSB-a u Zagrebu. Od 1997. zaposlen je na Institutu za mehaniku Tehničkoga sveučilišta Darmstadt, a od 1998. na Institutu za građevinsku i numeričku mehaniku Sveučilišta u Hannoveru. Na FESB-u u Splitu zaposlio se 2003., a 2010. bio izabran za redovitoga profesora. Na FSB-u u Zagrebu bavio se istraživanjem vezanim za elastoplastične formulacije modeliranja ljuski metodom konačnih elemenata. Na sveučilištima u Darmstadtu i Hannoveru razvija nove napredne formulacije kontaktnih konačnih elemenata. Nakon prelaska u Split istražuje u području eksperimentalne mehanike, razvija nove metode evaluacije materijala temeljene na aktivnoj termografiji. S Fakultetom za strojništvo u Mariboru ispituje i razvija ćelijaste materijale i metalne pjene. Član je znanstvenoga odbora Danubia Adria Society. Obnašao je dužnost predsjednika HDM-a. 
Dražan Kozak, inženjer strojarstva (Derventa, 1967). Diplomirao je 1991. na Strojarskom fakultetu u Slavonskom Brodu i doktorirao 2001. na Fakultetu strojarstva i brodogradnje u Zagrebu. Nakon diplomiranja zaposlio se na Strojarskom fakultetu u Slavonskom Brodu gdje je 2012. izabran za redovitoga profesora. Područje njegova znanstvenoga interesa su metoda konačnih elemenata, mehanika loma, procjena cjelovitosti konstrukcija posebno energetskih komponenti. Ekspert je za potrebe Hrvatske akreditacijske agencije u području posuda pod tlakom i sigurnosnih ventila. Obnašao je dužnost prodekana i dekana Strojarskoga fakulteta i prorektora Sveučilišta J. J. Strossmayera u Osijeku. Član je Uredničkoga odbora 14 časopisa. Predsjednik je međunarodne udruge International TEAM Society. Autor je sedam sveučilišnih udžbenika. Predsjednik je podružnice ESIS za Hrvatsku, koja djeluje pri HDM-u.

Tanja Jurčević Lulić, inženjerka strojarstva (Karlovac, 1968). Diplomirala je 1991. i doktorirala 1999. na FSB-u u Zagrebu, na kojem je ostala raditi nakon diplomiranja, a 2013. izabrana je za redovitu profesoricu. Istražuje u području biomehanike, tj. na primjeni mehanike krutih i deformabilnih tijela na rješavanje bioloških problema. Pridonijela je razvoju metoda dinamičke antropometrije, analize i simulacije gibanja čovjeka, numeričkom modeliranju procesa deformiranja bioloških tkiva u dentalnoj biomehanici, primjeni biomehanike u ergonomiji i razvoju modela za određivanje opterećenja čovjeka. Obnašala je više dužnosti, među ostalim bila je predstojnica Zavoda za tehničku mehaniku, prodekanica, član Senata Sveučilišta u Zagrebu, predsjednica Hrvatskoga ergonomijskoga društva i druge. Dobitnica je Velike Medalje FSB-a.

Mirela Galić, inženjerka građevinarstva (Mostar, 1970). Diplomirala je 1995. i doktorirala 2006. na Građevinskom fakultetu Sveučilišta u Splitu, na kojem je ostala raditi i izabrana je za redovitu profesoricu. Usavršavala se na Londonskom sveučilištu, Queen Mary College, London, Department of Civil Engineering. Istražuje u području paralelnoga programiranja za metodu konačno-diskretnih elemenata. Jedna je od urednica časopisa International fournal for Engineering Modelling. Obnašala je dužnost prodekanice GF-a u Splitu i tajnice HDM-a. 


\title{
LITERATURA
}

Alebić-Juretić, Ana: »Peter Salcher - The Mach's Corresponding Collaborator «, Proceedings Ernst Mach Centenary Conference 2016, Ernst Mach (1838-1916) - Life, Work and Influence. University of Vienna, Österreichische Akademie der Wissenschaften, June 15-18, 2016.

Alfirević, Ivo, Kalman, Žiha, Krajna, Tamara: »Povijest, uloga i značaj hrvatskih tehničkih časopisa«, Zbornik radova Petog susreta Hrvatskog društva za mehaniku, Terme Jezerčica, Donja Stubica, 6.-7. lipnja 2013.

Alf irević, Ivo: »Hrvatsko društvo za mehaniku 1969.-2007.«, Zbornik radova Prvog susreta Hrvatskoga društva za mehaniku, Rijeka 2007.

Andrassy, Mladen: »Devedeset godina Fakulteta strojarstva i brodogradnje Sveučilišta u Zagrebu«, Strojarstvo, 2009., 5, str. 415-421.

Borić, Marijana: »Znanost i filozofija u Hrvatskoj (1900-1960) u monografiji Žarka Dadića«, Prilozi za istraživanje hrvatske filozofske baštine, 2013., 1, str. 398-408.

Brčić, Vlatko: »Istorijat Jugoslovenskog društva za mehaniku«, Beograd, December 1994. Invited Lecture, Proceedings YUCTAM NIŠ-95, str. 2-34.

Dubrović, Ervin: Vojno-pomorska akademija u Rijeci 1866.-1914., Rijeka 2011.

Les Lettres Albanaises, Union des écrivains et artistes d'Albanie, Tirana 1984., str. 163.

Mach, Ernst, Salcher, Peter: »Photographische Fixirung der durch Projectile in der Luft eingeleiteten Vorgänge«, Sitzungsberichte der kaiserlichen Akademie der Wissenschaften. Mathematischnaturwissenschaftliche Classe, Fünfunneunzigster Band, Wien 1887., str. 764-781.

Salcher, Peter: Geschichte der k. u. k. Marine-Akademie. Carl Gerold's Sohn, Wien 1902.

Šimić, Vicko: Spomenica u povodu 75. obljetnice Zavoda za tehničku mehaniku 1920.-1995., Sveučilište u Zagrebu 1995.

Timoshenko, Stephen P.: As I Remember, Van Nostrand 1968.

\section{CROATIAN SCIENTISTS IN THE DEVELOPMENT OF $20^{\mathrm{TH}}$ CENTURY MECHANICAL ENGINEERING}

\author{
Ivo Alfirević \\ Faculty of Mechanical Engineering and Naval Architecture, Zagreb \\ ivo.alfirevic@fsb.hr
}

ABSTRACT: Mechanical engineering started to become distinct from classical mechanics on the turn of the $18^{\text {th }}$ to the $19^{\text {th }}$ century, i.e. at the beginning of the Industrial Revolution, prompted by the establishment of polytechnics in Europe. In Croatia, mechanical engineering began to develop in the second half of the $19^{\text {th }}$ century, intensifying after the establishment of the Royal Polytechnic in Zagreb in 1919. This paper also presents the biographies of distinguished Croatian and foreign scientists who contributed to the development of mechanical engineering in Croatia in the $20^{\text {th }}$ century.

Keywords: mechanical engineering; $20^{\text {th }}$ century; Peter Salcher; Ivan Blaž Lupis; Sándor Alexander Riegler; Vinko Dvořák; Vinko Hlavinka; Stjepan Prokofjevič Timošenko; Konstantin Čališev 